УДК 327

\title{
AZERBAIJANI-UKRAINIAN RELATIONS IN THE SPHERE OF ART IN THE ERA OF GLOBALIZATION
}

\section{АЗЕРБАЙДЖАНСЬКО-УКРАЇНСЬКІ ЗВ'ЯЗКИ В СФЕРІ МИСТЕЦТВА В ЕПОХУ ГЛОБАЛІЗАЦЇ̈}

\section{АЗЕРБАЙДЖАНО-УКРАИНСКИЕ СВЯЗИ В СФЕРЕ ИСКУССТВА В ЭПОХУ ГЛОБАЛИЗАЦИИ}

\section{Efendiyeva A. F.}

Post-graduate student of the Department of Diplomacy and Foreign Policy of Baku Slavic University. E-mail: sevinc.n@mail.ru

\section{Ефендісва А. Ф.}

Докторант кафедри Дипломатії i зовнішньої політики Бакинського слов'янського університету. E-mail sevinc.n@mail.ru

\section{Эфендиева А. Ф.}

Докторант кафедры Дипломатии и внешней политики Бакинского славянского университета. E-mail sevinc.n@mail.ru

\begin{abstract}
The article discusses the features of the strategy for the dynamic development of relations in the field of art of Azerbaijan and Ukraine. The successes of cooperation in the field of art, the further development of bilateral humanitarian ties, which served as a vivid example of strategic partnership between the republics in the new century, are noted. Bilateral and multilateral events are currently under way. States are trying to demonstrate the ideas of "equality" and "brotherhood" among themselves. Cultural ties between Ukraine and Azerbaijan are being carried out. Cultural ties with the two countries are subordinated primarily to political goals. It should be noted that historically, the Azerbaijani people have had extensive international relations. The rich culture of the Azerbaijani people also attracted various states. The effective development of Ukrainian-Azerbaijani cultural ties in the modern period is a clear demonstration of the construction of the foreign policy of both states in accordance with the requirements of the time. Monitoring the development of humanitarian relations in this aspect has a certain political science relevance. A humanitarian policy in the context of bilateral cooperation of states in the context of globalization requires constant updating of the form and content of relations in this area of international relations. Therefore, both in Azerbaijan and Ukraine, new short-term and long-term projects are constantly being developed, agreements and cooperation agreements are concluded for the further development of relations between the two countries in various fields of the humanitarian sphere.
\end{abstract}

Keywords: Azerbaijan, Ukraine, art, music, international relations, twin cities

Анотація. У статті розглядаються особливості стратегії динамічного розвитку відносин в галузі мистецтва Азербайджану та Украйни. Відзначено успіхи співпраці в сфері мистецтва, подальший розвиток двосторонніх гуманітарних зв'язків, які послужили яскравим прикладом стратегічного партнерства між республіками в новому столітті. Проводяться двосторонні і багатосторонні заходи в даний час. Держави намагаються 
демонструвати ідеї "рівності» $i$ «братства» між собою. Здійснюються культурні зв'язки між Україною та Азербайджаном. Культурні зв'язки з двома краӥнами підпорядковані переважно політичним иілям. Слід зазначити, щчо історично у азербайджанського народу були великі міжнародні зв'язки. Найбагатша культура азербайджанського народу також притягувала різні держави. Ефективний розвиток україно-азербайджанських культурних зв'язків в сучасний період є наочною демонстрачією побудови зовнішньої політики обох держав відповідно до вимог часу. Спостереження за розвитком гуманітарних відносин в даному аспекті має певну політологічну актуальність. Гуманітарна політика в контексті двостороннього співробітниитва держав в умовах глобалізації вимагає постійного оновлення форми $і$ змісту зв'язків в иій галузі міжнародних відносин. Тому як в Азербайджані, так $i$ в Украӥні постійно розробляються нові короткострокові $i$ довгострокові проекти, укладаються угоди і договори про співробітництво для подальшого розвитку відносин між двома країнами в різних галузях гуманітарної сфери.

Ключові слова: Азербайджан, Украйна, мистецттво, музика, міжнародні відносини, міста-побратими

Аннотация. B статье рассматриваются особенности стратегии динамичного развития отнотений в области искусства Азербайджана и Украины. Отмечень успехи сотрудничества в сфере искусства, дальнейшее развитие двусторонних гуманитарных связей, послуживших ярким примером стратегического партнерства между республиками в наступившем веке. Проводятся двусторонние $u$ многосторонние мероприятия $в$ настоящее время. Государства стараются демонстрировать идеи «равенства» $u$ «братства» между собой. Осуществляются культурные связи между Украиной и Азербайджаном. Культурные связи с двумя странами подчинень преимущественно политическим целям. Следует отметить, что исторически у азербайджанского народа имелись обширные международнье связи. Богатейшая культура азербайджанского народа также притягивала различные государства. Эффективное развитие украиноазербайджанских культурных связей в современный период является наглядной демонстрацией построения внешней политики обоих государств в соответствии $c$ требованиями времени. Наблюдение за развитием гуманитарных отношений в данном аспекте имеет определенную политологическую актуальность. Гуманитарная политика в контексте двустороннего сотрудничества государств в условиях глобализаиии требует постоянного обновления формы и содержания связей в этой области международных отношений. Поэтому как в Азербайджане, так и в Украине постоянно разрабатьваются новые краткосрочные и долгосрочные проекты, заключаются соглачения и договоры о сотрудничестве для дальнейшего развития отношений между двумя странами в различных областях гуманитарной сферы.

Ключевые слова: Азербайджан, Украина, искусство, музыка, международные отночения, города-побратимы

\section{Introduction.}

There is a large legal framework between Ukraine and Azerbaijan that regulates relations between our countries in the cultural sphere. The basic document in the field of cultural cooperation is the Agreement on cooperation in the field of culture and art between the Ministry of Culture and Arts of Ukraine and the Ministry of Culture of the Republic of Azerbaijan, signed in Kiev in 1997.

Since its signing, great positive changes have taken place in the Azerbaijani - Ukrainian cultural relations. The main large-scale in the Azerbaijani - Ukrainian cultural relations were and remain ties in the field of art. The dynamics of bilateral cultural cooperation between our states in the context of globalization requires a constant renewal of the form, types and content of ties in this area. Therefore, both in Azerbaijan and in Ukraine, new short-term and long-term projects are constantly being developed, agreements and cooperation agreements are being concluded for the 
further development of relations between the two countries in various fields of art. Naturally, globalization gave dynamics to relations in this area. In this sense, the study of the connection in the field of art in the era of globalization between Azerbaijan and Ukraine is very relevant.

The purpose of research is to analyze international relations between Azerbaijan and Ukraine in the field of culture

\section{Recent literature review.}

Relations in the field of art in the era of globalization between Azerbaijan and Ukraine are devoted to the scientific works of domestic and foreign scientists. Scientists of Azerbaijan paid special attention to studying the problems. So, in the work of G.N. Mamedov, A. Abbasov, E. Nadzhafov, N.S. Mamedzade, T.M. Aliyev, Z. Jafarova and others are investigating the comprehensive ties in the field of art of Azerbaijan with Ukraine.

In recent years, books and articles dedicated to cultural ties between our peoples have been published in Ukraine. Among foreign scientists, it is worth highlighting the works of such as Sokhan P.S., Parakhonsky B., Dergachev A, and others.

In these works, the authors propose expanding and increasing the effectiveness of these links. Relations in the field of art in the era of globalization between Azerbaijan and Ukraine are devoted to the scientific works of such domestic and foreign scientists: Mamedov G.G., Abbasov A., Najafov E., Mamedzade N. N. Abbasov A., Aliev.T.M., Dzhaparov.Z., And others. Among foreign scientists, it is worth highlighting the works of such as P. Sokhan, B. Parakhonsky, A. Dergachev, and others.

Main research results. Art is a spiritual treasure that improves and deepens the fraternal and friendly relations of the peoples of the world. Sometimes, it knows no boundaries, overcoming all obstacles, fills, spiritually enriches the hearts of people. Art is an ethnocultural code for its carrier. When it contains universal significance, when it has a high aesthetic taste, then overcoming the boundaries it penetrates the soul of people, delights and becomes their value.

Music is also a communication that has its own language. Therefore, art has its place among international humanitarian relations. The ways to implement it are diverse. Prof. $H$. Mammadov in his work "Azerbaijan-Eastern Europe: the history of intercultural cooperation" writes: "Cultural cooperation between Azerbaijan and the countries of Eastern Europe is carried out in different ways: touring, sending notes, phonograph records, discs, relations between composers and performers, participation in international music festivals and competitions, etc." [Мамедов: 2009]. Such events are mainly held in the form of anniversaries, international competitions, anniversaries, festivals, etc. For example, in June 2002 - on the Day of the Ukrainian Constitution People's Artist of the Azerbaijan Republic M. Magomayev and T. Senyavskaya gave a concert. And also on October 23-29, 2002 the staff of the Azerbaijan State Musical Theater named after Rashid Behbudov performed concert programs in such cities of Ukraine as Nikolayev, Dnepropetrovsk, Kharkov and Kiev [Мамедов: 2009].

Events related to the anniversary of the establishment of diplomatic relations also relate to the above. For example, on April 2-4, 2013, in honor of the 20th anniversary of Azerbaijan-Ukraine diplomatic relations in Ukraine, the days of Azerbaijani culture were held. In this regard, the Union of Composers of the two countries (Firangiz Alizade from Azerbaijan, Igor Shcherbakov from Ukraine) prepared a socio-cultural program. Under the motto Days of Azerbaijani Culture were the Minister of Culture and Tourism of Ukraine M. Shved, chairman of the M. Magomayev Cultural Center, Gurban Abbasov and the representative of the Diaspora Hikmet Javadov. M. Shved noted that, since the last years the cultural relations between Azerbaijan and Ukraine have gained a wide scale, we already see their results. The musical part was performed by the soloist of the Kievskaya Kamerata ensemble, People's Artist of Ukraine Valery Matyukhin. Here were performed "Garabagname", "Mugamsayagi" on the container, as well as the symphony "Nizami" by F. Amirov. At the end, F. Alizadeh notes: "Our music is evidence that in the history of the Azerbaijani people there were not only holidays, but also tragic pages, as well as in the history of each people" [Бабаева: 2018] 
At this event, the music told everyone the Karabakh realities and their universal tragedy: "Even from the rehearsal, many remembered "No comments" - the work of R. Khalilov, dedicated to the tragic events in the village of Khojaly in 1992. Three stages of the development of thought alternated in a single breath - an influx of sad memories that arose from afar, the revival of tragic scenes of events in dramatic comparisons, and finally, the deep, mournful afterword of the piano. Amazed-transmitted halftones struck, it sounded very organically and the tape recording (not reproduced in previous versions) played its expressive role. Transmitting the overall impression of the performance of this composition, I think that the opus "No comments" found its vivid embodiment in the performance of the Kiev Camerata" [Мамедалиева: 2013].

Then the National Symphony Orchestra of Ukraine, as well as the Honored Art Worker of Azerbaijan, conductor Fakhraddin Kerimov and folk instrument performers S. Pashazade and Ch. Mutallibova entered the stage of the Column Hall of the National Philharmonic named after N. Lisenko. The press wrote about the atmosphere of the concert:

"The brightly epic symphonic canvas "Koroglu" by S. Farajev, setting a magnificent tone throughout the concert, smoothly gave way to the classical model of A. Zeynalli - the song "My Country", which was warmly and sincerely performed by People's Artist of Ukraine Gurban Abbasov. In the "Monologue" by Rauf Aliyev, the image of the homeland was remembered in a peculiar, heroic and tragic spirit. The fantasy of Dadash Dadashov "Patterns" that followed, for the canon and symphony orchestra, introduced a brightly ethnic, genre flavor. Her delicately arranged and technically complex melodic part was masterfully performed by the soloist Chinara Mutallibova" [Мамедалиева: 2013]. Subsequent performances, especially the symphonic parable by Ch. Abbasova "Where are you, Ulyses?" deeply touched people, "Tales" by F. Alizade, "Azerbaijan Dance" by Musa Mirzoyev, mugam "Bayaty Shyraz" performed by J. Pashazade fascinated everyone. At the very end, one of Kara Karayev's masterpieces was performed by the People's Artist of Ukraine Bogdan Pivenko. Participants of the event admitted that the Days of Azerbaijani Culture in Ukraine left a deep mark in the memory of Ukrainians.

"It should be noted that for the purpose of international cultural cooperation in the musical sphere and its development, a number of musical societies function in the republic, such as "New Music", etc. The society was organized in 1995 by the Honored Art Worker, composer, Professor F. Garayev and conducts propaganda on the establishment of international relations, on the need for a worthy presentation of national music on the world stage. Moscow and other Eastern European colleagues highly appreciate the activities of the President of the Society F. Guliyev in the development and dissemination of our contemporary music, and thus a new page opens in the annals of Azerbaijani music. The New Music Society is a representative in such a prestigious organization as the Azerbaijan International Music Society, and also plays the role of an intermediary in creating business relations between Azerbaijani-Ukrainian and foreign performers. Art, as a universal method of cultural cooperation, plays an important role in the development of relations in all areas of public life. Therefore, creative forums in which representatives of various national schools of composers participate are of particular importance. And for this purpose, the modern music association "New Music" constantly holds festivals in Baku that study the new achievements of national and world music, and organizes trips of Azerbaijani musicians to different countries" [Мамедов: 2009].

On October 10, 2016, the Azerbaijani ensemble operating in Ukraine celebrated its 15th anniversary in the city of Kiev. The event was organized on the initiative of the Azerbaijan Embassy in Ukraine, the Joint Congress of Azerbaijanis of Ukraine, the Muslim Cultural Center named after Muslim Magomayev and the Association of Azerbaijani Youth of Ukraine [Hüseynli: 2017]. Also note that the ensemble was created by the Congress of Azerbaijanis of Ukraine under the leadership of the chairman of the Azerbaijan Cultural Center named after M. Magomayev and Gurban Abbasov. Such events are bilateral in nature. In this activity, the anniversaries of great masters also play a huge role. For example, on August 27, 2006, in connection with the anniversary - the 120th anniversary - of Uzeyir Hajibeyov, the comedy "Arshyn mal Alan" was shown on the stage of the Dnipropetrovsk National Theater named after T. Shevchenko. International 
competitions also play a huge role in this area. For example, in August 2003, with the assistance of the Ministry of Culture, Azerbaijani pop singers participated in the Yalta 2003 international competition, and T. Agayeva was awarded the Grand Prix of the competition. This can also include festivals. In 2003, through the Azerbaijani Embassy in Ukraine, in accordance with an agreement with the Dovzhenko Film Studio, the final work of the film "The shooting is canceled" was carried out in Kiev and the film was dubbed and presented to the audience there. Also in 2004, the works of V. Mustafazade were demonstrated at the IV International Audiovisual Festival and documents relating to him were sent to the National Radio of Ukraine. In June 2002, at the II International Festival of Children's Creativity of BSEC and GUUAM Member Countries, which was held in Crimea at the Artek International Children's Center, the Smile Children's Music Theater participated in Azerbaijan, which was distinguished by songs, dances and performances.

In order to disseminate the upcoming cultural processes, twentieth-century intercultural dialogues, the Ministry of Culture of the Republic of Azerbaijan together with the Initiative Center for Contemporary Music Sonor organized for the first time the I International Festival "Culture ... Contact 2003" of contemporary and traditional music. The festival was attended by the Bakustik Jazz group, representatives of modern Western music from different countries, as well as from Ukraine [Мамедалиева: 2013].

From May 7 to 14, 2003, the State Pantomime Theater represented the Republic of Azerbaijan at the Kiev Mayski International Theater Festival in Ukraine. On May 8, the State Pantomime Theater performed at the Ukrainian State Academic Musical Theater, and on May 9 the pantomime ballet Leyli and Majnun based on the eponymous poem by M. Fizuli was played at the Plastic Drama Theater.

From June 24 to July 3, 2007 in the city of Yevpatoria, Crimean region of Ukraine, the IX International Festival of Ancient Art "Bosphorus Lights" was held. The staff of the Baku Chamber Theater received an award for the play "Oedipus Rex" based on the work of the same name by Sophocles.

Festival. On May 15, 2017, during the organization of the Azerbaijan Embassy in Ukraine, the City Administration of Kiev and the Association of Azerbaijani Youth of Ukraine in Kiev, the ethno-jazz festival was held in the recreation park named after the Great Leader Heydar Aliyev. The Ambassador spoke about the historical merits of National Leader Heydar Aliyev in establishing economic, political, scientific, cultural relations between Azerbaijan and Ukraine and noted that from now on every year in May there will be an ethno-jazz festival dedicated to the memory of Great Leader Heydar Aliyev.

On January 6, 2018, outstanding masters of Ukraine participated in a large concert held as part of the XII International Humor and Music Festival "Fun" in Kabbalah at the Heydar Aliyev Congress Center.

As an artistic representative, contests play a huge role in Azerbaijani-Ukrainian relations. For example, the chairman of the Azerbaijan-Ukraine Union Elmar Mammadov said that in 2018 Ukraine plans to hold an international song contest dedicated to Muslim Magomayev. The organizers intend to collect at the competition, which will be held in Ukraine in the city of Truskavets, the best performers who will perform the songs of the legendary singer. The jury will include famous cultural and public figures of both countries. The chairman of the jury is planned to choose People's Artist of Ukraine Gurban Abbasov.

Participants of the competition, along with a demonstration of vocal data, must answer questions about the biography and achievements of Muslim Magomayev, about his films, concerts and about the musical works he created. The main purpose of the event is the popularization of Azerbaijani culture in Ukraine, as well as the strengthening of cultural relations between friendly states.

Azerbaijani artist Vagif Nagiyev, who lives in Ukraine, participates in prestigious international competitions and demonstrates excellent musical abilities. In an interview, he says: "This year we performed at concerts in 15 cities of Ukraine, dedicated to the 75th anniversary of the immortal singer Muslim Magomayev. I think that it's incredible not only to sing, but to stand on 
stage together with Vladimir Grishko. All opera singers, youth want to be on the same stage with him" [Бабаева: 2018].

Implementation of joint projects. Such projects are bilateral in nature, and activity is required from them; rapprochement of peoples, the elimination of barriers. For example, according to the Azerbaijani Embassy in Ukraine, the Ministry of Culture of Ukraine and the embassy agreed to hold a joint project "My Song". According to this project, concerts will be organized with the participation of famous singers from both countries. "Within the framework of the project, concerts will be organized with the participation of famous singers, soloists, opera performers of both countries. The first such concert, dedicated to the 75th anniversary of the world famous opera and pop singer, composer, People's Artist of the USSR Muslim Magomayev, will be held at the end of October in Kiev. People's artist Vladimir Grishko and opera and pop singers will perform from Ukraine under his leadership, and Azerbaijan's famous opera and pop singers Azer Zeynalov, Afag Abbasova and Samir Jafarov" (a new project is beginning to strengthen cultural relations between Azerbaijan and Ukraine) [Бабаева: 2018].

Relations between museums also occupy a large place within the framework of bilateral cultural relations. On December 9, 2016, a cooperation agreement was signed between the National Museum of Art of Azerbaijan and the Taras Shevchenko National Museum of Ukraine.

The agreement will give rise to mutual scientific research, the exchange of experiences of museum workers, the preparation of joint exhibitions and the establishment of AzerbaijaniUkrainian cultural relations. At the same time, this cooperation agreement will serve to spread Ukrainian culture in Azerbaijan, Azerbaijani culture in Ukraine" [Бабаева: 2018].

Relations in the field of theater between the two countries also received great success.

"The theater plays a big role in the Azerbaijani-Ukrainian humanitarian relations" The development of Azerbaijani theaters shows itself in the international exchange of experiences, which is expanding from year to year and gives positive results. New performances, tours, of course, adorn the boiling theatrical life. The state program "Azerbaijan Theaters 2009-2019" was an important step in the development of this industry and contributed to the entry into a new stage of our rich stage art. Today, the Azerbaijani theater conquers world scenes, is the author of international initiatives, the owner of prestigious events. Over the past two years, our theaters have successfully represented Azerbaijan at international events held in 20 countries, 11 theater groups from foreign countries have come on tour, about 30 well-known foreign directors, choreographers, theater artists have staged performances on the country's stages. According to the state program, in September 2014 the I International Theater Festival was organized in Sheki with the participation of 12 state and 2 foreign theaters operating in the republic. On November 3-6, 2014 the Baku International Theater Conference was held for the third time, which is of great importance from the point of view discussion of priority issues of theatrical art, exchange of experience, integration of the Azerbaijani theater in the world theater society. The conference "The Place of Theater Art in the Universal Values of Multiculturalism" was attended by approximately 150 renowned theater specialists, international theater critics, directors, artists, choreographers and playwrights from 40 countries (USA, UK, Canada, France, Italy, South Africa, Netherlands, Australia, Ireland, Russia, the United Arab Emirates, Spain, Morocco, Ukraine, Poland, Turkey, Lithuania, Georgia, Bulgaria, Germany, Greece, Israel, etc.). The development of cinema is a priority in the field of culture and occupies a significant place in the activities of the Ministry of Culture and Tourism. The orders signed by the president created favorable conditions for the development of this industry. The II International Festival of Tourist Films, held last year in Baku, was a significant event. At the festival, 405 films from 55 countries were presented. Another project in the field of cinema - the II Baku International Festival of Sports Films - gathered in one place 115 screen works from 33 countries. On October 23-29, 2002 the collective of the Azerbaijan State Song Theater named after R. Behbudov - Honored Artists of the Republic V. Aliyev, sisters Mammadov Gulyaz and Guljanag, harmonist K. Vezirov, dancers A. Alkhasova, Z. Ibrahimova, G. Talybova and other members of the ensemble - performed in the cities of Nikolaev, Dnepropetrovsk, Zaporozhye, 
Kharkov, and Kiev with concert programs dedicated to the 11th anniversary of the independence of the Republic of Azerbaijan and the demonstration of Azerbaijani culture [Мамедов: 2009].

From October 4 to 7, 2007, the Golden Autumn music festival was held in Baku. At this festival a man's sextet chapel of Ukraine performed. We know that in the modern world theater is one of the main forms of international humanitarian relations. Theatrical groups of Azerbaijan successfully performed at international festivals held in Kiev.

"The creative relationship between the famous choreographers of Azerbaijan and the Ukrainian ballet company, the exchange of experience, participation in anniversaries and festivals have become a source of expansion of cultural relations between peoples. Through the embassy in Ukraine, according to the agreement with the Dovzhenko film studio, the final work on the film "The shooting is canceled" took place in Kiev. There, the film was dubbed in Russian and a screening was organized for Ukrainian filmmakers. In October 2004, films of Ukrainian directors were shown at the VI International Audio-Visual Festival. On June 13, 2005, the editor-in-chief of the analytical programs of Ukrainian National Television N. Bazvin interviewed UNESCO Goodwill Ambassador P. Bulbuloglu for the broadcast "Audience" [Мамедов: 2009].

Television plays a significant role in the system of humanitarian relations between Azerbaijan and Ukraine.

"In 2002, the ceremonial opening of the representative office of Azerbaijani television in Kiev was held in Ukraine. The programs "President", "Politics and Jazz", "Ordinary Courier", "Facts and Comments", and others Ukrainian national television covers the socio-political life, culture and traditions of Azerbaijan, the activities of the Azerbaijani community in Ukraine. On March 26, 2002, Ambassador T. Aliyev gave a 45-minute interview about cultural relations to the prestigious channel of Ukraine's MBT; on May 11, Deputy Interior Minister M. Mammadguliyev gave an interview to the World: Consciousness program of the UT-I television and the INTER TV channel" [Мамедов: 2009].

The forums also have a special position in the Azerbaijani-Ukrainian humanitarian relations.

"On March 7, 2018, the Forum "Unlimited: Unlimited Art", held in Ukraine at the initiative of the British Council, was attended by 200 representatives from Britain, Ukraine, Azerbaijan and Georgia.

Director of the Cinema Center Nizami Leyli Mirzayeva along with representatives of the Britis Council participated in the forum "Unlimited: Unlimited Art" held in Kiev. At the opening of the forum, the First Lady of Ukraine noted the importance of involving people with disabilities in active public life, preparing inclusive projects in this area, and also mentioned that these projects are part of state policy. During the discussion panels, Leyli Mirzayeva shared her experience with the participants of the forum, telling them about the project of the Nizami cinema center "Cinema for All", within the framework of which the first screening of films with sound translation for people with hearing and speech impairments was organized in Azerbaijan, and noted the success of the project" (Cinema center Nizami represented Azerbaijan in Ukraine at the forum "Unlimited: unlimited art") [Мамедалиева: 2013].

Ambassador Extraordinary and Plenipotentiary of Ukraine to Azerbaijan A.Mishenko, taking into account the prospects for cultural relations between the countries, noted: "Let's approach the culture from a broad perspective, recall several events in the field of music and organized exhibitions. For example, the famous Ukrainian artist and photographer Yevgeny Kovtonyuk held a photo exhibition in Baku from August to September last year. Azerbaijani artists also often hold such events. The Azerbaijani Embassy in Ukraine is very active in this direction. In the field of theater, there are cooperative relationships. Last year, the Puppet Theater of Poltava represented Ukraine at the International Puppet Theater Festival, which was held in Baku. It was also a great opportunity to familiarize children with the culture of another country. For example, my daughter is studying in Baku. She performs local national dances, at school they even staged a small play "Leyli and Majnun". I see that my eight-year-old daughter began to sing Azerbaijani songs. And of course, we welcome this. If a small Ukrainian woman at this age respects Azerbaijani 
culture and customs, she will reach a higher level when she is a politician, deputy, diplomat. Azerbaijani children in Ukraine also participate in events. Our country has a large Azerbaijani diaspora. Here, the Ukrainian diaspora is also active and participates in the events of the embassy" [Мамед-заде: 2006].

The state program "Azerbaijan Theaters 2009-2019" was an important step in the development of this industry and contributed to the entry into a new stage of our rich stage art.

In 2012, the Unions of Composers of Ukraine and Azerbaijan prepared a socio-cultural program dedicated to the 20th anniversary of the establishment of diplomatic relations between the two countries. In this regard, it was decided to hold Culture Days of these countries in March 2012 in Azerbaijan and in March 2013 in Ukraine.

The Days of Azerbaijani Culture were held on April 2-4, 2013 in Ukraine, and the Days of Ukrainian Culture were held on October 9, 2015 in Baku. The events were attended by the Ambassador of Ukraine to Azerbaijan A. Mishchenko, who noted that such events contribute to further expansion of existing relations between the two peoples [Бабаева: 2018].

On June 16-19, 2013, the Days of Ukrainian Culture were held in the Azerbaijan Philharmonic named after M. Magomayev. The event was attended by representatives of the ministries of culture and tourism of both countries, as well as deputies of the Milli Majlis of Azerbaijan and employees of the diplomatic corps of the Embassy of Ukraine. After the official part of the event, a concert was held with the participation of the world famous National Honored Academic Dance Ensemble of Ukraine named after P.Virsky. In the lobby of the Philharmonic, the participants got acquainted with a photo exhibition dedicated to Ukraine [В Азербайджане пройдут Дни культуры Украиньл: 2013].

Conclusions. Analysis of international relations in the field of art of Azerbaijan and Ukraine in the era of globalization indicates the expansion of the scale, boundaries and volumes of these ties. The musical art of Azerbaijan has acted as an important instrument of peace, cooperation and friendship between peoples.

So, in the context of globalization, cultural cooperation between the peoples of Azerbaijan and Ukraine turned into a unique channel of spiritual communication and mutual understanding of people.

It can be concluded that the future of the world depends not on confrontation and collision, but on the victory of good, the development of cultural dialogue and cultural ties. So, one of the most important building blocks in art cooperation is equality and mutual respect. These factors are also important to remove obstacles to its implementation.

\section{References}

1. Мамедов Г. Н. (2009) "Роль Бакинского славянского университета в развитии культурных отношений между Азербайджаном и Украиной” [The role of Baku Slavic University in the development of cultural relations between Azerbaijan and Ukraine]. Культура народов Причерноморья. Научный журнал. №163, с. 137.

2. Бабаева Дж. (2018) Киноцентр “Низами” представил Азербайджан на форуме "Unlimited: Искусство без границ" в Украине [Cinema center "Nizami" represented Azerbaijan at the forum "Unlimited: Art without borders" in Ukraine]

https://www.trend.az/life/culture/2869574.html

3. Мамедалиева Т. (2013) Украинско-азербайджанские музыкальные связи (дни азербайджанской музыкальной культуры в Киеве) (2013) [Ukrainian-Azerbaijani music relations (days of the Azerbaijani music culture in Kiev)] https://www.kultura.az/news/20130517085725881

4. Hüseynli E. (2017) Kiyevdə Heydər Oliyevin xatirəsinə həsr olunmuş caz festivalı keçirilib [Jazz festival dedicated to Heydar Aliyev's memory held in Kiev]

http://m.gomap.az/Info/Detailed_News.aspx?id=38758\&lng=az 
5. Мамед-заде Н.С. (2006) Взаимоотношения Азербайджанской Республики со славянскими странами СНГ и Восточной Европы [Relations between the Azerbaijan Republic and the slavic countries of the cis and eastern europe]

http://www.anl.az/el/m/mn_vaps.pdf

6. В Азербайджане пройдут Дни культуры Украины (2013) [Azerbaijan will host Days of Ukrainian Culture] https://www.trend.az/life/socium/2159866.html 